\title{
Alexis de Tocqueville, Het Ancien Régime en de Revolutie
}

\author{
Irawan Sewandono
}

Alexis de Tocqueville, Het Ancien Régime en de Revolutie, vertaling Berend en Bram Sommer, inleiding Martin Sommer, nawoord Meindert Fennema (Amsterdam: Boom uitgevers, 2019), ISBN 978-90-2442-091-9, 384 p.

Tocqueville vraagt zich af hoe het komt dat de revolutionaire vonk juist in 1789 in Parijs in het kruitvat is geslagen (p. 68). De kracht van zijn boek is dat het aanzet tot verder denken. Het is een soepele en literaire vertaling, die recht doet aan de aanstekelijke stijl van dit laatste werk van hem: trefzeker en niet saai. Heel Europa, van Polen tot Ierland, kende bijna dezelfde instellingen: koninklijk hof, willekeurige en steeds zwaardere centrale belastingdruk, onontkoombare herendiensten, aan de grond gebonden feodale rechten op het platteland en verplichte aansluiting bij de stedelijke gilden (p. 61). Hij heeft een scherp oog voor de geleidelijkheid van veranderingen. Hij is gebiologeerd door het absolutisme van Lodewijk XIV, de moderniteit van Lodewijk XVI, de dictatuur van Napoleon, de restauratie van de Bourbons en de omwentelingen van 1830 en 1848.

Wie aan dit boek begint, moet zich voor ogen houden dat burger hier de vertaling kan zijn van drie verschillende begrippen: 'bourgeois' als lid van de stedelijke burgerij, 'citoyen' als betrokken bij het corps politique van Rousseau (voetnoot p. 136) en 'roturier' als niet adellijk persoon (p. 141). Het zinsverband is bepalend om te kunnen begrijpen of het gaat om geestelijkheid, welgestelde burgerij of eenvoudige dorpse boeren. Het woord burger kan ten slotte ook nog handwerkslieden en fabrieksarbeiders in de stad Parijs omvatten (voetnoot p. 129).

Tocqueville stelt voorop dat de Franse boer al in de achttiende eeuw grondeigenaar was geworden en dat agrarische grond extreem was versnipperd. Al jaren lang kon de grootgrondbezitter het hoofd slechts boven water houden door zijn landgoederen bij stukjes en beetjes te verkopen (p. 73). Het eerste hoofdthema van deel II van het boek is de centralisatie in Frankrijk. In de achttiende eeuw was de band tussen grondbezit en bestuur verloren gegaan en daardoor had de adel geen functie meer in de politiek en het lokale bestuur. De bestuurlijke macht was al sinds Lodewijk XIV gecentraliseerd in Parijs, met als verlengstuk in de provincies de intendanten van de koning en in de kantons hun gevolmachtigden (p. 76).

Voor de adel restte nog slechts een groot aantal niet-politieke privileges en voorrechten. Om te beginnen moeten genoemd de erfelijke titels en landgoederen die in Frankrijk onverdeeld overgingen van vader op oudste zoon (p. 133). Het tweede hoofdthema van deel II is dat feodale belastingen zwaar en onevenredig drukten op de gewone bevolking. Tocqueville gaat verder met de privileges van de lokale landheer, die onlosmakelijk waren gebonden aan andermans grond (p. 78, 
details eindnoot 44). Volstrekt anders was de vrijstelling voor de adel van de directe belastingen. Deze was oorspronkelijk slechts een compensatie voor de middeleeuwse plicht van de edelen om hun koning bij te staan in zijn oorlogen. Hun vrijstelling bleef echter bewaard na de invoering van een algemene militieplicht van zes jaar voor wie daarvoor bij loting was aangewezen (p. 89 en 133). Aan het eind van hoofdstuk I van deel II verschijnt het leidmotief van het boek: naar mate de algemene belastingdruk zwaarder werd, nam de betekenis van deze vrijstelling toe en kreeg zij een weerzinwekkende omvang (p. 141-142, eindnoot 32). Door dit alles was de Franse boer de adel intens gaan haten (p. 81).

Met deze expositie in hoofdstuk I van deel II lijkt Tocqueville zijn kruit te hebben verschoten. Ook het vervolg blijft echter zeer de moeite van het lezen waard. Wat maakte het Ancien Régime zo bijzonder? De originaliteit van het boek schuilt in het uitgebreide archiefonderzoek en zijn selectie van aansprekende casussen (voorwoord, p. 34-35), verzameld zonder digitale hulpmiddelen. Naast het leidmotief van de jalousie van burgers en boeren staan in deel II nog drie andere motieven centraal: (1) de bestuurlijke centralisatie en trek naar de stad, (2) de economische en politieke emancipatie van de burgerij en (3) de revolutionaire voortrekkersrol van geleerde schrijvers.

Ten eerste stond in het hart van het koninkrijk een orgaan waarin alle macht bij elkaar kwam: de Raad van de Koning. Deze Raad was alles tegelijk: hooggerechtshof, want hij kon het vonnis van alle gewone rechtbanken vernietigen, en hoogste beroepsinstantie, want uiteindelijk kon hij alle bestuursrechtelijke kwesties beslissen. Daarnaast maakte de Raad als adviseur van de regering in feite het merendeel van de wetten, stelde hij de belastingen vast en verdeelde de opbrengst. Alles kwam uiteindelijk bij hem samen, en bij hem begon de beweging die met alles in verbinding stond. Desondanks had hij geen eigen bevoegdheden. Hij besliste slechts in naam van de koning (p. 85). Aan de intendanten in de provincie was de uitvoering van alle edicten van de koning en arresten van de Raad overgedragen. Ook al stond beroep open op de Raad en kon hij richtlijnen aan zijn intendanten geven, in feite hadden zij in hun provincie in eerste aanleg alle macht in handen. Ook zij waren bestuurder en rechter tegelijk (p. 86-87). Zij oefenden op het platteland een schrikbewind uit met behulp van lokale detachementen bereden politie (p. 91). Daarbij kwam, zoals al aangestipt, dat alle geschillen over de uitvoering van edicten en arresten voor de intendant moesten worden gebracht om door hem te worden beslist, met beroep op de Raad. Zelfs in zaken die geen enkel verband hielden met het openbaar gezag, kon de Raad ingrijpen met een zgn. evocatie waarmee hij een zaak uit handen van de gewone rechter nam en aan zichzelf trok (p. 106-107). Wie hier origineel en vertaling naast elkaar legt, ziet dat vertalen erg lastig kan zijn. Al die historische Franse instellingen worden door Tocqueville beschreven in termen van zijn eigen tijd en die moeten door de vertaler worden omgezet in de nu gebruikelijke Nederlandse juridische begrippen.

De bestuurlijke arm van Parijs reikte tot in de meest afgelegen dorpen (p. 100). Dit leidde tot veel bureaucratie, bijvoorbeeld de casus van de kerktoren van het 
dorpje Ivry, île-de-France. Het dak lekte en moest worden gerepareerd. Maanden en maanden waren nodig voor de briefwisseling over de verdeling van de herstelkosten over de parochianen en de invordering ervan (eindnoot 22). Ook in demografische zin was er sprake van centralisatie. Uit alle hoeken van Frankrijk waren arbeiders naar Parijs verhuisd. Beetje bij beetje klonterden zij in sommige wijken samen totdat deze bijna uitsluitend door hen werden bewoond. Nergens anders kon men zich immers zo gemakkelijk aan het juk van de gilden onttrekken (p. 129).

Ten tweede leken volgens Tocqueville de mensen in de achttiende eeuw in Frankrijk nogal op elkaar. Ter illustratie van de verpaupering van de adel haalt hij het verslag aan van een intendant over het jaarlijkse diner van de adel in zijn provincie. Nadat de edelen samen hadden gegeten en de mis hadden bijgewoond, keerden die armoezaaiers weer huiswaarts, sommigen te paard, anderen te voet (p. 134). In Frankrijk, zo citeert Tocqueville een zegsman, werd de burger steeds dikker op kosten van de adel. In veel gevallen was hij net zo rijk als een edelman en soms zelfs rijker. Daarbij kwam dat zijn rijkdom vaak gelijksoortig was: hoewel hij in de stad woonde, was hij vaak grondbezitter. In wezen waren alle mensen op elkaar gaan lijken, althans zij die boven het volk stonden (p. 134-135).

Ten derde wijst Tocqueville de schrijvers aan als de hoofdschuldigen. Dit is het steeds terugkerende rondo-thema van deel III. In de achttiende eeuw gaven zij de toon aan in het Franse politieke leven. Op grote afstand van de praktijk konden zij zich overgeven aan abstracte theorieën, zonder enig benul van het echte bestuur. Zij konden hun fantasie de vrije loop laten over de inrichting van de staat en hadden geen idee van de gevaren van een echte revolutie (p. 199-200). Hun simpele idealen van vrijheid en gelijkheid sloegen aan bij het Franse volk dat, zoals eerder gezegd, in de stad al betrekkelijk vrij en gelijk was. Zijn politieke opvoeding werd verzorgd door de schrijvers en dat heeft nog het meest bijgedragen aan het eigen karakter van de Franse Revolutie (p. 205-206).

Tocqueville biedt een gedegen beeld van de bestuurlijk-politieke verhoudingen onder het Ancien Régime. De verbazing van de burggraaf over de haat onder het volk is een interessante narratief. Het boek leest als een trein. Voor wie daarvan houdt, staan hier en daar ook de nodige klassieke stijlfiguren. Het is bovenal een bron van weetjes die leiden tot nieuwe inzichten bij de lezer. Naar mijn indruk is Frankrijk echter in veel opzichten helemaal niet zo bijzonder. De mythe van de Gouden Eeuw met zijn rijke Amsterdamse kooplui blijft ons beeld van de latere eeuwen vertekenen en zelfs dat van de nadagen van de Republiek der Zeven Provinciën. Op de OV-fiets door Gelderland en Limburg dringt tot je door dat die wijdverbreide Noord-Europese feodaliteit daar tot de Bataafse Revolutie nog springlevend was (Dolly Verhoeven en Iris Dracht, De grenzen van Gelre. Fietsen door historisch landschap, Zutphen: WalburgPers, 2019). Ook die omwenteling strekte zich uit over een paar decennia (Simon Schama, Patriotten en bevrijders, Amsterdam: Agon, 1989). En na het Engelse tussenbewind waren de landsregering in Buitenzorg met zijn residenten en controleurs van het Binnenlands Bestuur en het Indische Cultuurstelsel van Van den Bosch een imitatie van de 
prerevolutionaire verhoudingen in Frankrijk (Wim van den Doel, De stille macht, Amsterdam: Bert Bakker, 1994, resp. Angelie Sens, De kolonieman, Amsterdam: Balans, 2019).

Een eyeopener is dat de bestuursrechtspraak in Frankrijk al in de achttiende eeuw was onttrokken aan de gewone rechterlijke macht. Dat verklaart waarom Montesquieu bij machtenscheiding alleen dacht aan de gewone rechtspraak over misdrijven en geschillen tussen particulieren (De l'Esprit des lois, Boek XI, hoofdstuk VI, de Constitutie van Engeland; voor zijn eerste grondwetten van de eenheidsstaat heeft Van Hogendrop veel klakkeloos overgenomen van Montesquieu). Niet alles vloeit rechtstreeks voort uit de nationale scheiding van drie staatsfuncties en hun toedeling aan aparte organen. Waartoe verplichten tegenwoordig Europees recht en mensenrechtenverdragen? Wat moet de rechter overlaten aan de parlementaire wetgever en lagere regelgevers nu onze poldercultuur in verval begint te raken? Hoe ver mag de rechter treden in de autonomie van de decentrale overheden en de beoordelingsruimte van het bestuur? Vanuit het Franse verleden werpt Tocqueville enig nieuw licht op de gecompliceerde relatie in Nederland tussen enerzijds onze grondwettelijke machtenscheiding en anderzijds diverse bestuursrechtelijke fenomenen uit ons eigen verleden en heden: het Conflictenbesluit van koning Willem I, de rechtspraak over de bevoegdheidsafbakening tussen gewone en bestuursrechter, de intensiteit van toetsing door de bestuursrechter, de bestuurlijke sancties en vooral: het besluitbegrip van de Awb. 